
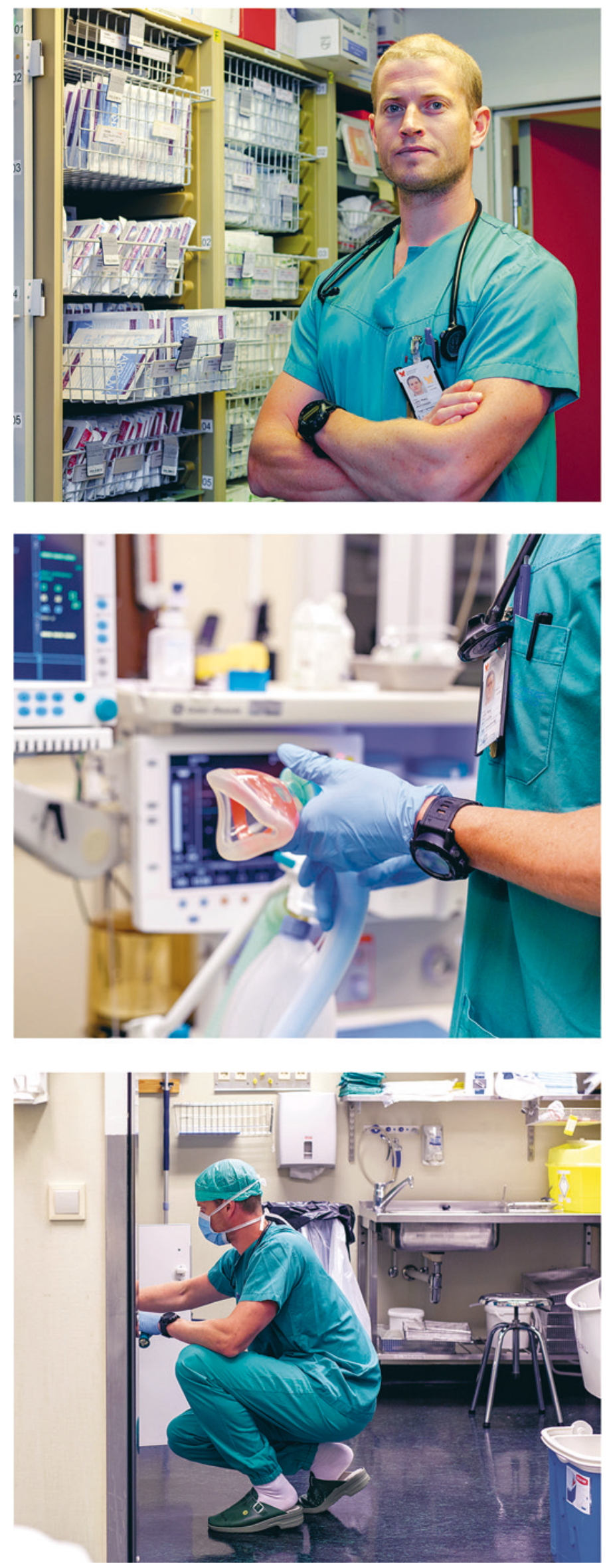

Foto: Niklas Lello

\section{Krevende beslutninger}

\author{
Lars Prag Antonsen er lege i spesialisering i anestesi \\ ved Sykehuset Østfold. Han mener at beslutnings- \\ kompetanse er en sentral ferdighet i faget - og at \\ dette kan øves.
}

Skjer det noe interessant innen anestesien for tiden? Et tema som ofte diskuteres er hvordan vi som anestesileger kan bli bedre kliniske beslutningstakere. Vår hverdag preges av hektiske vakter der beslutninger må tas hurtig og på grunnlag av ufullstendig informasjon. Dette stiller store krav til anestesilegen. Kunnskapsgrunnlaget tilsier at medisinske beslutninger preges av kognitive feilkilder, individuelle preferanser og unøyaktige sannsynlighetsberegninger, selv når diagnosen er kjent og det foreligger retningslinjer for behandling. Høy faglig kompetanse er viktig, men sentralt er også innsikt i hvordan hjernen påvirkes av slike feilkilder under press. Den tradisjonelle medisinske modellen er bygd opp rundt at vi gjennom anamnese og undersøkelser samler inn relevant informasjon. Dette er et godt utgangspunkt. Vi må tilnærme oss problemstillinger systematisk og vi må søke mest mulig informasjon. Samtidig er det avgjørende å erkjenne at mangel på informasjon oftest vil være normaltilstanden. Vi må være komfortable med å ta avgjørelser basert på ufullstendige opplysninger når alternativene mangler eller tar for lang tid. Dette kan øves. Forsvarets operative avdelinger anser eksempelvis beslutningskompetanse som en sentral ferdighet og legger stor vekt på dette under trening.

\section{Vil du anbefale en ny og spennende artikkel?}

Stiegler gir en interessant innføring $\mathrm{i}$ kognitive prosesser ved beslutningstaking $\mathrm{i}$ anestesien, og han beskriver også teknikker som kan brukes i utdanning (1). I tillegg vil jeg trekke frem boken Thinking, fast and slow av Kahneman. Den er ikke spesifikk for anestesifaget, men gir tankevekkende innblikk i hvor feilbarlig en beslutningsprosess er (2).

\section{Hva er ditt favoritthjelpemiddel på jobb?}

Et klart hode og en god bakvakt.

\section{Anbefalt litteratur}

1. Stiegler MP, Tung A. Cognitive processes in anesthesiology decision making. Anesthesiology 2014; 120: 204-17.

2. Kahneman D. Thinking, fast and slow. New York, NY: Farrar, Straus and Giroux, 2011.

Har du tips til personer vi kan intervjue? Ta kontakt med lise.morkved.helsingen@legeforeningen.no 